\title{
MANAJEMEN RISIKO LIKUIDITAS PADA PERBANKAN SYARIAH
}

\author{
Wiwin Winanti \\ Prodi perbankan Syariah STIE Syariah Indonesia Purwakarta \\ Jl. Veteran no 150-152 Purwakarta 41118 Jawa Barat INDONESIA \\ wiwinwinanti441@gmail.com
}

Intisari- Manajemen likuiditas yang membahas mengenai posisi uang kas suatu bank dan kemampuannya untuk memenuhi kewajiban (membayar utang) tepat waktu. Manajemen likuiditas merupakan salah satu fungsi terpenting yang dilakukan oleh lembaga perbankan, dan bertujuan untuk mepelajari masalah resiko likuiditas dan harus bisa mengendalikan likuiditas dalam suatu perbankan syariah. Pentingnya penilaian atas likuiditas suatu bank, merupakan salah satu cara untuk bisa menentukan apakah bank tersebut dalam kondisi yang sehat, cukup sehat, kurang sehat, dan tidak sehat. Salah satu penyebab kebangkrutan suatu bank adalah karena ketidak mampuannya dalam memenuhi kebutuhan likuiditasnya.

Kata kunci: manjemen risiko, likuiditas, bank syariah

Abstract - Liquidity management that discusses the position of a bank's cash and its ability to fulfill obligations or pay debts on time. Liquidity management is the most important function carriedout by banking institutions, and aims to study liquidity risk issues and must be able to control liquidity in an islamic banking. The importance of assessing the liquidity of a bank is one way to determine whether the bank is healthy, unhealthy and unhealthy, one of the causes of bank bankruptcy is due to ist inability to meet its liquidity needs.

Keywords — risk management, liquidity, Islamic bank

\section{Pendahuluan}

Secara umum tugas utama bank adalah menghimpun dana dari masyarakat dalam bentuk simpanan. Kemudian dana yang telah terkumpul tersebut disalurkan kembali kepada mas-yarakat dalam bentuk pinjaman (kredit), serta memberikan jasa-jasa bank lainnya. Untuk bisa menghimpun dana dari masyarakat, maka bank memiliki keharusan untuk meyakin-kan nasabah bahwa uang yang mereka titipkan dijamin ke-amanannya. Dengan demikian, agar bisa memberikan keamanan kepada para nasabah, maka bank tersebut haruslah likuid. ${ }^{1}$

Mengenai likuiditas di dunia perbankan, merupakan satu keharusan yang harus dilakukan, baik itu oleh pihak perbankan, praktisi keuangan, ataupun pihak-pihak ketiga yang berencana menitipkan dananya di bank. Pentingnya penilaian atas likuiditas suatu bank, merupakan salah satu cara untuk bisa menentukan apakah bank tersebut dalam kondisi yang sehat, cukup sehat, kurang sehat, dan tidak sehat. Salah satu penyebab

${ }^{1}$ Achmad Fathany, "Manajemen Likuiditas Bank Syariah", dari website (http://myfhany.blogspot.com/2015/05/manajemen-likuiditas myfhany.html?m=1). 01/02/2019 17.26 WIB. kebangkrutan suatu bank adalah karena ketidak mampuanyai dalam memenuhi kebutuhan likuiditasnya. Oleh karena itu, likuiditas yang tersedia harus cukup sehingga tidak mengganggu kebutuhan operasional. $^{2}$

Bank syariah memiliki kewajiban untuk melunasi atau disebut juga dengan likuiditas. Likuiditas merupakan salah satu faktor penentu sehatnya perbankan syariah dalam melunasi dana para deposannya yang ingin menarik kembali kredit yang diberikan dengan menggunakan rasio. Rasio tersebut berbanding terbalik dengan rasio profitabilitas karena rasio profitabilitas digunakan untuk mengukur efektivitas perusahaan untuk mendapatkan keuntungan, sehingga se-makin tinggi rasio pitabilitas maka rasio likuiditas semakin kecil. Hal tersebut disebabkan karena dana yang diperlukan untuk membiayai kreditnya semakin kecil . Namun semakin kecil rasio likuiditas akan ber-pengaruh pada naiknya tingkat profitabilitas. ${ }^{3}$

2 My Fingers, "Manajemen Likuiditas", dari wibsate (http://makalahkuindonesia.blogspot.com/2017/04/manajemen -likuiditas.html?m=1).01/02/2019 17.26 WIB

3 Febby Varas Savitri, "Risiko Likuiditas Pada Bank Syariah Di Indonesia" dari website 


\section{EKSISBANK Vol. 3 No. 1 Juni 2019}

\section{TELAAH/KRITIK TERHADAP FENOMENA MANAJEMEN RISIKO LIKUIDITAS}

Risiko likuiditas adalah risiko akibat ketidak mampuan bank syariah untuk memenuhi kewajiban yang jatuh tempo dari sumber pendanaan arus kas dan atau aset likuid berkualitas tinggi yang dapat digunakan, tanpa mengganggu aktifitas, dan kondisi keuangan bank. Jadi risiko likuiditas itu risiko yang timbul dari ketidak mampuan bank syariah dalam memenuhi kewajibannya pada waktu yang telah ditentukan pada nasabah. ${ }^{4}$

Ketidak mampuan memperoleh sumber dana arus kas sehingga menimbulkan resiko likuiditas dapat disebabkan antara lain:

a. Ketidak mampuan menghasilkan arus kas, baik yang berasal dari aset produktf maupun yang berasal dari penjualan aset termasuk aset likuid.

b. Ketidak mampuan menghasilkan arus kas yang berasal dari penghimpunan dana, transaksi antar bank syariah, dan pinjaman yang diterima

Resiko likuiditas sering pula dimaknai sebagai kerugian potensial yang didapat dari ketidak mampuan bank dalam memenuhi kewajiban yang jatuh tempo, baik mendanai aset yang telah dimiliki maupun mendanai pertumbuhan aset bank tanpa mengeluarkan biaya atau mengalami kerugian yang melebihi toleransi bank. Resiko kredit dan resiko likuiditas merupakan resiko yang paling fundamental dalam industri perbankan. Disebut fundamental karena pemicu utama kebangkrutan yang dialami oleh bank. ${ }^{5}$ Oleh karna itu jika suatu bank tidak bisa mengatasi masalah fundamental tersebut. Sudah dipastikan bank tersebut akan kehilangan nasabahnya.

Menyatakan likuiditas penting untuk bank syariah dalam menjalankan aktivitas bisnisnya, mengatasi kebutuhan mendesak, memuaskan permintaan nasabah terhadap pinjam-an, dan memberikan freksibilitas dalam meraih kesempatan investasi menarik dan memungkinkan. Likuiditas yang tersedia harus cukup, tidak boleh terlalu kecil sehingga mengganggu kebutuhan oprasional sehari-hari, tetapi juga tidak boleh terlalu besar karena akan menurunkan efisiensi dan berdampak pada

(http://makalahkuindonesia.blogspot.com/2017/04/ manajemenlikuiditas.html?m-1) 01/02/2019 17.26 WIB.

44 Bambang Rianto Rustam, "Manajemen Risiko Perbankan Syariah di Indonesia”,(Jakarta: Salaemba Empat, 2013) 147

55 Bambang Rianto, "Manajemen Risiko Perbankan Syariah di Indonesia. rendahnya tingkat profitabilitas. Jadi jika suatu bank bisa mengelola likuiditas tersebut, maka nasabah-nasabah akan merasa puas yang akan berdampak pada bertambahnya nasabah baru dan memajukan bank syariah tersebut. ${ }^{6}$

Menguraikan bahwa bank syariah harus mampu memenuhi kebutuhan likuiditasnya dengan memelihara likuiditas aset atau menciptakan likuiditas dengan cara meminjam dana. Apabila bank menahan aset seperti surat beharga yang dapat dijual untuk memenuhi kebutuhan dananya, resiko likuiditas menjadi rendah. Sementara itu, penahanan aset dalam bentuk surat beharga akan membatasi pendapatan karena bank memperoleh tingkat peng-hasilan yang lebih tinggi dari pembiyaan.

Faktor kuncinya adalah bank tidak dapat leluasa me-maksimumkan pendapatan karena adanya desakan kebutuhan likuiditas. ${ }^{7}$ Karena itu, bank harus memperhatikan jumlah likuiditas yang tepat. Terlalu banyak likuiditas akan me-ngorbankan tingkat pendapatan dan terlalu sedikit akan berpotensi meminjam dana yang berkaitan meningkatnya biaya dana dan menurunkan profitabilitas. Lebih-lebih bagi bank syariah yang dilarang melakukan pinjaman dana yang berbasis bunga, tentu akan lebih sulit untuk memperoleh dana. Bank syariah harus pintar dan bijak dalam mengambil keputusan tentang menahan atau tidaknya aset atau surat berharga milik nasabah. Apabila bank syariah tidak bijak dalam mengambil keputusan tersebut, maka akan berpengaruh pada likuiditas bank syariah itu sendiri.

Oleh karena itu, tujuan utama Manajemen Risiko Likuiditas adalah untuk menimbulkan kemungkinan ketidak mampuan bank syariah dalam memperoleh sumber, pendanaan arus kas.

Secara lebih spesifik tujuan dari manajemen risiko likuiditas adalah sebagai berikut. ${ }^{8}$

1. Memelihara kecukupan likuiditas bank sehingga setiap waktu mampu memenuhi kewajiban bank yang jatuh tempo.

2. Memelihara kecukupan likuiditas bank untuk mendukung pertumbuhan aset bank yang berkelanjutan.

3. Menjaga likuiditas bank pada tingkat yang optimal sehingga biaya atas pengelolaan

66 Antonio, "Bank Syariah Dari Teori ke Praket". (Jakarta: Gema Insani Press, 2001)

7 Zaena Arifinl, "Dasar-Dasar Manajemen Bank Syariah”. (Bandung: Alva Beta, 2002). 265

8 Bambang Rinato, "Manajemen Risiko Perbankan Syariah di Indonesia”. 150 
likuiditas berada dalam batas yang dapat ditoleransi.

4. Menjaga tingkat kepercayaan nasabah terhadap sistem perbankan.

Besar kecilnya resiko likuiditas ini banyak ditentukan oleh hal-hal sebagai berikut.

1. Kecermatan perencanaan arus kas bedasar-kan pada prediksi pembiyaan dan prediksi pertumbuhan dana, termasuk mencermati tingkat fluktuasi.

2. Ketepatan dan mengatur stuktur dana, termasuk kecukupan dana non bagi hasil Alamat email wajib bagi penulis korespondensi (corresponding author). Ke-terangan sebagai penulis korespondensi dituliskan setelah alamat email.

3. Ketersediaan aset yang siap dikonversikan menjadi kas.

4. Kemampuan akses kepasar antar bank atau sumber dana lainnya termasuk fasilitas lender of last resort.

Faktor internal dan eksternal penyebab resiko likuiditas : 9

a. Internal

1) Exposeres lembaran tinggi

2) Bank sangat bergantung pada perusahaan jangka pendek

3) Kesenjangan dalam tanggal jatuh tempo aset dan liabilitas.

4) Bank-bank ekspansi aset cepat melebihi dana yang tersedia di sisi kewajiban.

5) Konsentrasi deposito dalam tenor jangka pendek.

6) Kurang alokasi dalam instrumen pemerintah cair.

7) Lebih sedikit penempatan dana dalam deposito jangka panjang.

b. Eksternal

1) Pasar keuangan dan deposan yang sensitif.

2) Guncangan ekonomi eksternal dan insternal.

3) Kinerja ekonomi rendah atau lambat

4) Mengurangi kepercayaan deposan pada sektor perbankan.

5) Faktor nonekonomi (kerusuhan politik dan lain-lain).

6) Tiba-tiba dan penarikan likuiditas besarbesaran dari deposan.

9 Bambang Rianto, "Manajemen Risiko Perbankan Syariah Di Indonesia:. 149

\section{TELAAH/KRITIK TERHADAP FENOMENA RISIKO INHEREN}

Risiko inheren merupakan risiko yang melekat pada kegiatan bisnis bank syariah, baik yang dapat di kuantiflkasi-kan maupun yang tidak, yang berpotensi memengaruhi posisi keuangan bank..$^{10}$

Oleh karena itu, penting bagi bank untuk mengelola likuiditas yang cukup sehingga mampu menghadapi perubah-an-perubahan kondisi keuangan dan ekonomi apapun. Masalah pengelolan likuiditas adalah masalah yang ber-hubungan dengan ke-mampuan suatu perusahaan untuk memenuhi kewajiban finansialnya yang segera harus dipenuhi. Jumlah alat-alat pembayaran (alat likuid) yang dimiliki oleh suatu perusahaan pada suatu saat merupakan kekuatan mem-bayar dari perusahaan yang bersangkutan. Suatu perusaha-an yang mempunyai kekuatan membayar belum tentu dapat memenuhi. Jadi jika suatu bank atau perusahaan sudah bisa mengelola dan memenuhi kewajiban finansalnya, mereka akan siap untuk mengatasi masalah keuangan dan ekonomi yang akan datang kedepannya.

Pada bank syariah, dana nasabah dikelola dalam bentuk titipan maupun investasi. Cara titipan dan investasi jelas berbeda dengan deposito pada bank konvensional dimana deposito merupakan upaya membungakan uang. Konsep dana titipan berarti kapan saja si nasabah membutuhkan, maka bank syariah harus dapat memenuhinya, akibatnya dana titipan menjadi sangat likuid. Likuiditas yang tinggi inilah membuat dana titipan kurang memenuhi syarat suatu investasi yang membutuhkan pengendapan dana. Jadi bank bisa mengambil semua keuntungan dari dana titip tersebut tanpa dibagi dengan nasabah, asalkan dana nasabah tidak berkurang sedikitpun. ${ }^{11}$

Karena pengendapan dananya tidak lama alias cuma titipan maka bank boleh saja tidak memberikan imbal hasil. Sedang-kan jika dana nasabah tersebut diinvestasikan, maka karena konsep investasi adalah usaha yang menanggung risiko, artinya setiap kesempatan untuk memperoleh ke-untungan dari usaha yang dilaksanakan, didalam-nya terdapat pula risiko untuk menerima kerugian, maka antara nasabah dan banknya samasama saling berbagi baik keuntungan maupun risiko.

10 Bambang Rianto, "Manajemen Risiko Perbankan Syariah di Indonesia” 150

11 Risa Ariani6, "Manajemen Likuiditas Perbankan Syariah". Di Akses Dari Website (http://risaariani6.blogspot.com /2012/06/manajemenlikuiditas-perbankan-syariah.html.). 11-2018 


\section{TELAAH/KRITIK DALAM FENOMENA PRINSIP-PRINSIP ISLAMIC FINANCIAL SERVICES BOARD}

Risiko likuiditas adalah elemen kunci untuk manajemen likuiditas efektif. Sebagaimana dimaklumi bahwa bank syariah harus mencari beragam sumber dana untuk membiayai aktivitas pembiayaan dan investasinya. Bank syariah harus bisa menyediakan beragam sumber dana untuk membayar permintaan pemilik rekening, menyediakan dana committed untuk transaksi musyarakah, dan untuk menyediakan arus kas untuk pembayaran biaya lainnya. Bagi hasil antar bank kurang menarik karena final settlementnya harus menunggu selesai perhitungan cash basis pendapatan bank yang biasanya baru terlaksana pada akhir bulan. ${ }^{12}$

\section{A. Klasifikasi Risiko}

Risiko likuiditas dapat diklasifikasikan menjadi likuiditas endogen dan likuiditas eksogen. Likuiditas endogen adalah likuiditas yang melekat pada setiap jenis aset bank itu sendiri. Aset bank memiliki dua bentuk likuiditas endogen, yaitu sebagai berikut.

1. Likuiditas yang berkaitan dengan kemampuan bank untuk menjual aset itu di pasar yang likuid secara cepat.

2. Likuiditas yang berkaitan dengan karekteristik likuiditas setiap aset tersebut. Contoh. aset bank berupa instrumen pasar uang umumnya memiliki karekteristik likuiditas yang lebih tinggi dari pasar modal.

Likuiditas eksogen adalah likuiditas yang ditimbulkan oleh stuktur kewajiban bank. Bank dengan stuktur kewajiban yang bertumpu pada dana jangka pendek akan menghadapi risiko likuiditas yang lebih tinggi ketimbang bank dengan stuktur kewajiban yang seimbang antara dana jangka pendek dan jangka panjang. Risiko likuiditas dapat melekat pada produk penghimpunan dana dan produk penyaluran dana. Pada produk penghimpunan dana yang terdiri atas giro, tabungan, dan deposito, berdasarkan pada sifatnya risiko likuiditasnya adalah sebagai berikut: ${ }^{13}$

1. Giro memiliki risiko likuiditas tertinggi karena produk giro ditunjukan untuk keperluan transaksional dan dapat ditarik setiap waktu.

\footnotetext{
12 Bambang Rianti, “ Manajemen Perbankan Syariah Di Indonesia".152

13 Bambang Rianto"Manajemen Risiko Perbankan Syariah Di Indonesia", 152
}

2. Tabungan memiliki risiko likuiditas lebih rendah dari giro karena sifatnya simpanan dan dapat ditarik setiap waktu.

3. Deposito memiliki risiko paling rendah karena hanya bisa dicairkan pada waktu jatuh tempo.

Berdasarkan pada prinsip syariah yang mendasarinya terdapat dua jenis akad penghimpunan dana, yaitu wadi'ah atau mudharabah. Produk dengan akad wadi'ah memiliki risiko likuiditas lebih tinggi karena pemilik dana tidak turut menanggung kerugian maupun pendapatan dari penggunaan dana itu oleh bank. Bank harus bertanggung jawab atas keutuhan dana nasabah

Produk dengan akad mudharabah memiliki risiko yang lebih rendah karena pemilik dana ikut berpartisipasi atas risiko pendapatan dari penggunaan dana itu oleh bank. Akad mudharabah dapat diklasifikasikan dalam dua tipe. Pertama, mudharabah muqayyadah (restricted investment account = RIA) dan mudharabah mutlaqah (unrestricted investment account $=U R I A)$. Pada RIA off balance sheet bank mempertemukan pemilik dana dan pelaksana usaha sehingga memiliki risiko likuiditas lebih rendah dari RIA on balance sheet. Dalam URIA, bank dapat menggunakan dana yang telah dihimpun sehingga memiliki risiko likuiditas lebih tinggi: ${ }^{14}$

B. Risiko Likuiditas Pada Produk Penyaluran Dana

Berdasarkan pada karekteristik dan sifatnya risiko masing-masing produk penyaluran dana dapat dipetakan sebagai berikut.

1. Pembiayaan dengan akad mudharabah /musyarakah memiliki risiko likuiditas tertinggi.

2. Pembiayaan dengan akad murabahah, istishna'lsalam, ijarah memiliki risiko likuiditas lebih rendah dari mudharabah.

3. Pembiayaan dengan akad qardh, rahn, wakalah, kafalah, hawalah dengan risiko terendah

Bank harus memelihara likuiditas yang mencukupi untuk memenuhi kewajibannya pada seluruh waktu, oleh karena itu, mereka perlu mempertimbangkan sifat dari bank syariah, aktivitas bisnisnya, dan lingkungan pasar modal. Bank harus memiliki kebijakan manajemen likuiditas yang dikaji secara periodik untuk menciptakan hal hal sebagai berikut. ${ }^{15}$

14 Bambang Rianto," Manajemen Risiko Perbankan Syariah Di Indonesia”, 153

${ }^{15}$ Endang Setyowati, "Manajemen Likuiditas Perbankan Syariah”. website (http://shariaeconomy.blogspot.com/2008/ 11 manajemen-likuiditas-perbankan-syariah.html) 2008.112018 


\section{EKSISBANK Vol. 3 No. 1 Juni 2019}

1. Strategi untuk memelihara likuiditas termasuk pe-ngawasan board of director (BOD) dan manajemen senior.

2. Kerangka pengembangan dan implementasi proses pengukuran dan pemantauan likuiditas yang sehat.

3. Sistem yang cukup untuk memantau dan melaporkan eksposur likuiditas dalam dasar periodik.

4. Kapasitas pendanaan yang cukup dengan referensi kepada keinginan dan kemampuan pemegang saham untuk memenuhi modal tambahan jika diperlukan.

5. Akses untuk likuiditas melalui realisasi aset tetap.

6. Manajemen krisis likuiditas.

Kebijakan harus menghubungkan faktor kualitatif

dan kuantitatif. Faktor kuantitatif termasuk keragaman dan sumber dana, konsentrasi dana, dan kebergantungan aset yang mudah dijual, ketersediaan stand by line dari dana eksternal.

Faktor kualitatif termasuk penilaian kemampuan manajemen, skill manajemen treasury, dan hubungan masyarakat, kualitas Sistem informasi manajemen (SIM), reputasi bank, keinginan, dan kemampuan pemegang saham memberikan modal tambahan dalam kasus cabang atau cabang pembantu dimana kantor pusat mampu memberikan likuiditas.

C. Pengukuran Dan Pemantauan Likuiditas

Bank harus mengidentifikasikan kebutuhan likuiditas dengan membentuk maturity ladders berdasarkan pada time band yang tepat. Bank harus memiliki kriteria sendiri untuk klasifikasi arus kasnya termasuk metode behavioral dan bisa juga mempertimbangkan tipe arus kas sebagai berikut: ${ }^{16}$.

1. Arus kas yang diketahui-jatuh tempo jumlah yang diketahui. Termasuk kategori ini piutang dari murabahah, ijarah IMB.

2. Kondisional, arus kas yang bisa diprediksi (salam, istishna') biasanya didefinisikan dalam tipe kontrak berdasarkan pada dasar dari syarat yang disetujui.

3. Kondisional dan arus kas yang tidak bisa diprediksi. Beberapa kasus investasi yang terdapat pada musyarakah.

Ketika dilakukan kalkulasi dari kebutuhan dana bersih yang biasanya dipengaruhi oleh situasi likuiditas, bank dapat berhubungan dengan ekspektasi manajemen dan ekspektasi pemegang

16 Bambang Rianto,"Manajemen Risiko Perbankan Syariah Di Indonesia”, 156 rekening investasi. Dasar ini diasumsikan bahwa dana akan dibayar pada kontraktual saat tanggal jatuh tempo, maka tidak realistis untuk mengasumsikan bahwa semua pemegang rekening investasi akan tetap memelihara dananya di bank sampai jatuh tempo, oleh karena itu, penilaian internal dari ekspektasi mereka dan insentif akan menjadi dasar dari net funding requirement $($ NFR $){ }^{17}$

\section{Mitigasi Risiko Likuiditas}

Bank syariah harus mengambil risiko likuiditas yang sepadan dengan kemampuan mereka untuk memiliki ldana berbasis syariah lain untuk mengurangi risiko tersebut. Bankhams menilai keperluan dan kemampuan akses ke sumber dana yang tersedia. Bank syariah memiliki beberapa sumber dana dalam pengelolaan likuiditasnya, yaitu sebagai berikut:

1. Arus kas dari aktivitas perbankan

2. Realisasi dari perdagangan aset yang diinvestasikan

3. Sekuritisasi aset

4. Kapasitas akses pemegang saham dan kantor pusat

Manajemen likuiditas bank berdasarkan pada perjanjian kontraktual dan prosedur Iikuidasi perlu menghindari likuidasi aset pada harga yang tidak menguntungkan. penurunan modal pemegang rekening, dan kerusakan reputasi. Bank harus memiliki rencana kontingensi likuiditas pada berbagai tahapan krisis likuiditas. Untuk itu, bank harus mendefinisikan tahapan-tahapan sebagai berikut: ${ }^{18}$.

1. Identifikasi gap likuiditas atau situasi yang menyebabkan terjadinya peristiwa pe-narikan.

2. Kebutuhan aset likuidasi atau investasi untuk me-menuhi situasi gap likuiditas.

3. Pengukuran darurat yang diambil jika langkah sebelumnya gagal memenuhi gap likuiditas.

Jika memungkinkan bank harus memasukan rencana kontingensi beberapa faktor dan tindakan pada setiap tahapan-tahapan sebagai berikut.

1. Memegang aset likuiditas yang berkualitas tinggi yang bisa dijual.

2. Profil aset lain dan kebutuhan likuiditas aset ini.

3. Penilaian kepatuhan syariah dan ketersedia-an produk dana di pasar termasuk kerja sama yang memungkinkan dengan bank syariah lain atau lembaga keuangan lain untuk mengakses pendanaan sementara.

17 Bambang Riant.," Manajemen Risiko Perbankan Syariah Di Indonesia”, 157

18 Bambang Rianto, "Manajemen Risiko Perbankan Syariah Di Indonesia”, 158 


\section{EKSISBANK Vol. 3 No. 1 Juni 2019}

4. Pengaturan likuiditas yang memungkinkan dengan bank sentral.

5. Pembentukan manajemen krisis atau pe-tugas yang bertanggung jawab untuk mengambil tindakan pada tahapan yang berbeda dalam krisis likuiditas.

6. Pemberitahuan prosedur komunikasi dengan kantor pusat bank dan otoritasnya. Bagaimanapun bank harus bisa mengupayakan kerja sama tersebut bisa dimiliki.

\section{TELAAH/KRITIK DALAM FENOMENA PENERAPAN MANAJEMEN RISIKO}

Penerapan manajemen risiko untuk risiko likuiditas bagi bank syariah, baik secara indivudual maupun bagi bank secara konsolidasi dengan perusahaan anak setidaknya mencakup hal-hal sebagai berikut:

A. Pengawasan aktif dewan komisaris, direksi, dan DPS

Semua bank syariah wajib melakukan penerapan manajemen risiko melalui pengawasan aktif dewan komisaris, direksi, dan DPS untuk risiko likuiditas, selain itu, bank syariah juga melaksanakan pengawasan aktif serta perlu juga menambahkan penerapan beberapa hal dalam tiap aspek pengawasan aktif dewan komisaris dan direksi, sebagai berikut: ${ }^{19}$

1. Kewenangan dan tanggung jawab dewan komisaris dan direksi

a. Dewan komisaris dan direksi bertanggung jawab untuk memastikan bahwa penerapan manajemen risiko untuk risiko likuiditas telah sesuai dengan tujuan strategis, skala, karekteristik bisnis, dan profil risiko likuiditas bank syariah, termasuk memastikan integrasi penerapan manajemen risiko untuk risiko likuiditas dengan risiko risiko lainnya yang dapat berdampak pada posisi likuiditas bank syariah.

b. Wewenang dan tanggung jawab dewan komisaris dalam penerapan manajemen risiko untuk risiko likuiditas antara lain adalah melakukan persetujuan dan evaluasi berkala mengenai kebijakan dan strategi manajemen risiko untuk risiko likuiditas termasuk rencana pendanaan darurat. Evaluasi berkala dilakukan setidaknya satu kali dalam satu tahun atau

19 Bambang Rianto, "Manajemen Risiko Perbankan Syariah Di Indonesia”, 159 dalam frekuensi yang lebih tinggi dalam hal terdapat perubahan factor-faktor yang mempengaruhi kegiatan usaha bank syariah secara signifikan.

c. Wewenang dan tanggung jawab direksi setidaknya meliputi:

1) Memantau posisi dan risiko likuiditas secara berkala, baik pada situasi normal maupun pada situasi pasar yang tidak menguntungkan.

2) Melakukan evaluasi terhadap posisi dan risiko likuiditas bank syariah setidaknya satu bulan sekali.

d. Wewenang dan tanggung jawab DPS

1) Dewan Pengawas Syariah harus melakukan evaluasi atas kebijakan manajemen risiko khususnya aspek risiko likuiditas yang terkait dengan pemenuhan Prinsip Syariah.

2) Dewan Pengawas Syariah harus mengevaluasi pertanggung jawaban direksi atas pelaksanaan kebijakan manajemen risiko khususnya aspek risiko likuiditas yang terkait dengan pe- menuhan Prinsip Syariah.

e. Sumber daya insani

Direksi harus memastikan bahwa setiap fungsi/unit yang bertanggung jawab dalam pengelolaan risiko likuiditas memiliki sumber daya insani dengan kompetensi yang memadai, antara lain pada ALCO. treasury.

f. Organisasi manajemen risiko likuiditas

Bank syariah wajib memiliki komite pengelolaan likuiditas yang bertanggung jawab untuk melakukan pengelolaan likuiditas bank syariah, antara lain seperti ALCO. ${ }^{20}$

B. Kebijakan, prosedur, dan penetapan limit

Dalam pelaksanaan kebijakan, prosedur, dan penetapan limit untuk risiko likuiditas, bank syariah perlu menambahkan penerapan beberapa hal dalam tiap aspek kebijakan. prosedur, dan penetapan limit, sebagai berikut: ${ }^{21}$

1. Strategi manajcmen risiko Penyusunan strategi untuk risiko likuiditas perlu disusun untuk meminimalkan kemungkinan ketidak mampuan bank syariah dalam memperoleh sumber pendanaan arus kas.

20 Bambang Rianto, "Manajemen Risiko Perbankan Syariah Di Indonesia”, 160

21 Bambang Rianto, "Manajemen Risiko Perbankan Syariah Di Indonesia”, 160 
2. Tingkat risiko yang akan diambil dan toleransi risiko

3. Limit risiko likuiditas harus konsisten dan relevan dengan bisnis bank syariah. kompleksitas kegiatan usaha, toleransi risiko, karekteristik produk, valuta, pasar dimana bank syariah tersebut aktif melakukan transaksi, data historis, tingkat profltabilitas, dan modal yang tersedia.

C. Proses identifikasi,pengukuran,pemantauan, dan pengen-dalian risiko, serta SIM risiko likuiditas.

Bank syariah melakukan penerapan manajemen risiko melalui proses identifikasi, pengukuran, pemantauan, dan pengendalian risiko, serta SIM risiko untuk risiko likuiditas, selain itu bank syariah juga perlu menambahkan penerapan beberapa hal dalam tiap proses dimaksud, sebagai berikut: ${ }^{22}$

1. Identifikasi risiko likuiditas.

a. Dalam rangka melakukan identifikasi risiko likuiditas, bank syariah harus melakukan analisis terhadap seluruh sumber risiko likuiditas.

b. Bank syariah harus melakukan analisis terhadap eksposur risiko lainnya yang dapat meningkatkan risiko likuiditas, antara lain risiko pasar, risiko kredit, risiko operasional, dan risiko hukum. Pada umumnya, risiko likuiditas seringkali ditimbulkan oleh kelemahan atau permasalahan yang di-timbulkan oleh risiko lain sehingga identifikasi risiko harus mencakup pula kaitan antara risiko likuiditas dengan risiko lainnya

2. pengukuran risiko likuiditas

a. Bank syariah wajib memiliki alat pengukuran yang dapat menguantifikasi risiko likuiditas secara tepat waktu dan komprehensif.

b. Alat pengukuran tersebut setidaknya meliputi hal hal sebagai berikut: ${ }^{23}$

1) Rasio likuiditas, yaitu rasio keuangan yang menggambarkan indikator likuiditas dan mengukur kemampuan bank syariah untuk memenuhi kewajiban jangka pendek.

2) Profil maturitas, yaitu pemetaan posisi aset, kewajiban, dan rekening administratif ke dalam skala waktu

22 Bambang Rianto, "Manajemen Risiko Perbankan Syariah Di Indonesia”, 162

23 Bambang Rianto, "Manajemen Risiko Perbankan Syariah Di Indonesia”, 163 tertentu berdasarkan pada sisa jangka waktu sampai dengan jatuh tempo.

3. Pemantauan risiko likuiditas

Pemantauan risiko likuiditas yang dilakukan bank syariah hams memperhatikan indikator peringatan dini untuk mengetahui potensi peningkatan risiko likuiditas bank syariah. ${ }^{24}$

4. Pengendalian risiko likuiditas

a. Pengendalian risiko likuiditas dilakukan melalui strategi pendanaan, Pengelolaan posisi likuiditas dan risiko likuiditas harian, pengelolaan posisi likuiditas, dan risiko likuiditas intragrup Pengelola-an aset likuid yang berkualitas tinggi, dan rencana pendanaan darurat

b. Strategi pendanaan mencakup strategi diversifikasi sumber dan jangka waktu pendanaan yang di-kaitkan dengan karekteristik dan rencana bisnis bank syariah.

5. Sistem informasi manajemen risiko likuiditas

Bank syariah harus memiliki SIM risiko yang memadai dan andal untuk mendukung pelaksanaan proses identifikasi, pengukuran, pemantauan, dan pengendalian, serta pelaporan risiko likuiditas dalam kondisi normal dan kondisi krisis secara lengkap, akurat, mutakhit, utuh dan berkesinambung-an. ${ }^{25}$

\section{TELAAH/KRITIK DALAM FENOMENA SISTEM PENGENDALIAN INTERNAL}

Bank syariah melakukan penerapan manajemen risiko melalui pelaksanaan Sistem pengendalian internal untuk risiko likuiditas, selain itu, bank syariah juga perlu menambahkan penerapan beberapa hal dalam tiap aspek sistem pengendalian internal, yaitu sebagai berikut.

a. Bank syariah harus menerapkan pengendalian internal dan kaji ulang independen yang memadai terhadap penerap-an manajemen risiko untuk risiko likuiditas yang dilaksanakan oleh Satuan Kerja Audit Internal (SKAI) atau oleh Satuan Kerja Manajemen Risiko (SKMR).

b. Pengendalian internal terhadap proses penerapan manajemen risiko untuk risiko likuiditas yang dilakukan oleh SKAI antara lain mencakup.
24 Bambang Rianto, "Manajemen Risiko Perbankan Syariah Di Indonesia”, 165

${ }^{25}$ Bambang Rianto, "Manajemen Risiko Perbankan Syariah Di Indonesia”, 168 


\section{EKSISBANK Vol. 3 No. 1 Juni 2019}

1) Kecukupan tata kelola risiko likuiditas, termasuk pengawasan aktif dewan kornisaris, dan direksi.

2) Kecukupan kerangka manajemen risiko untuk risiko likuiditas

c. Kaji ulang independen yang dilakukan oleh SKMR antara lain mencakup hal hal sebagai berikut.

1) Kepatuhan pada kebijakan dan prosedur ma-najemen risiko untuk risiko likuiditas termasuk dalam pengelolaan posisi likuiditas dan risiko likuiditas, komposisi aset, dan kewajiban, aset likuid berkualitas tinggi, dan kepatuhan pada limit.

2) Kinerja model pengukuran risiko likuiditas, antara lain berdasarkan pada perbandingan antara hasil pengukuran risiko likuiditas dengan nilai aktual.

d. Kelemahan yang teridentifikasi dalam pengendalian internal dan kaji ulang independen hams dilaporkan kepada pihakpihak yang berwenang untuk ditindak-lanjuti.

\section{TELAAH/KRITIK DALAM FENOMENA RIVIEW MANAJEMEN RISIKO LIKUIDITAS DI INDONESIA}

Standar perbankan intenasional mengungkapkan penting-nya hal-hal berikut ini dalam mengelola manajemen likuiditas bank: ${ }^{26}$

a. Penentuan kebijakan manajemen likuiditas yang akurat, bisa dipahami dan akomodatif.

b. Adanya Komite Aset dan Liabilitas (ALCO).

c. Pembentukan sistem informasi untuk pemantauan dan pelaporan serta.

d. Sistem pengendalian internal yang memadai untuk pengelolaan likuiditas bank. Literatur ini memberikan beberapa teknik mitigasi risiko likuiditas dan instrumen keuangan yang bisa digunakan untuk memenuhi ke-butuhan likuiditas dari nasabah penyimpan dana.

literatur dan pedoman syariah dalam pengelolaan risiko likuiditas memberikan saran agar bank syariah mengelola risiko likuiditas dengan mengikut sertakan peran aktif dari deposan, pengusaha, dan bank syariah sendiri dalam mengantisipasi problem dengan kooperatif. Untuk itu bank dapat:

1. Memiliki stand by reserves.

2. pengaturan redemption dari deposito

${ }^{26}$ Ismail Rifki. "The Management Of Liquidity Risk The Caseof Inonesia”,. \{New York, Durham University,2010). 21
3. mengupayakan mitigasi business losses dan default, baik dalam pembiay aan berbasis ekuitas maupun debtfinancing

4. menyiapkan perjanjian kerja sama likuiditas dengan perusahaan induk Selain itu, untuk memenuhi kebutuhan dana regular yang predictable bank syariah dapat:

a. Menjual instrumen keuangan syariah jangka pendek.

b. Menjual instrumen keuangan syariah jangka panjang.

c. Meminjam dari pasar uang Islam. Sementara itu, untuk memenuhi unpredictable irregular demand liquidity bank syariah dapat
a) Meminjam dari perusahaan induk
b) Meminjam dari pemegang saham
c) Fasilitas darurat BI/Otoritas Iasa Keuangan (OJK)
d) Bail out dari pemerintah.

Dalam industri perbankan syariah ini mengidentiflkasi adanya struktur organisasi yang tidak optimal dalam hubungannya dengan pengelolaan likuiditas. Temuan ini juga menunjukkan bahwa terdapat estimasi permintaan yang signiflkan terhadap kebutuhan likuiditas jangka pendek dari deposan yang dianalisis dari sumber dana likuiditasnya (tipe produk simpanan). Analisis lebih lanjut juga menunjukkan bahwa kebijakan pembiayaan aIokasi dana dan cara dari bank syariah mengelola permintaan likuiditas dengan menggunakan instrument likuiditas Tier 1, Tier 2, dan Tier 3. Sampai dengan saat ini, ketiganya sukses dikelola untuk memenuhi kebutuhan likuiditas dari deposan, namun tidak ideal dari perspektif syariah. Melalui penggunaan model ekonometrik, variabel yang mempresentasikan perilaku likuiditas deposan dari model liabilitas. Variabel itu adalah: ${ }^{27}$

\section{SBI Rate}

2. Besaran benefit yang diterima dari deposito bank syariah pada masa yang lalu

3. Besaran bagi hasil yang dibayarkan bank syariah pada jangka pendek

4. Biaya operasi perbankan dan

5. Pendapatan dari pembiayaan bank syariah.

Perilaku likuiditas dari sisi pengusaha yang dinilai dari modal aset menunjukkan faktor yang menentukan adalah $:^{28}$

${ }^{27}$ Ismail Rifki. "The Management Of Liquidity Risk The Caseof Inonesia”. \{New York, Durham University,2010). 24

28 Bambang Rianto "Manajemen Risiko Perbankan Syariah Di Indonesia”. 170 


\section{EKSISBANK Vol. 3 No. 1 Juni 2019}

1. Profit dari pembiayaan non operasional

2. Besaran bagi hasil yang dibayarkan bank syariah ke deposan

3. Hasil dari keputusan sebelumnya dalam investasi operasional pembiayaan

4. Kinerja mitra bisnis dan prospek proyek yang akan dibiayai

5. Biaya operasional perbankan.

Khusus model cadangan likuiditas menunjukkan faktor paling penting dalam penentuan posisi optimum cadangan likuiditas, yaitu:

1. Bagi hasil yang dibayarkan bank ke deposan

2. Posisi sebelumnya dari cadangan likuiditas

3. The prior investment dalam operasional pembiayaan, dan

4. Profit dari operasional pembiayaan.

Untuk mencegah liquidity runs beberapa kondisi yang hams dipenuhi: ${ }^{29}$

1. Edukasi pada deposan dan publik secara intensif dari pemerintah, regulator. dan ulama

2. Perbaikan dari struktur likuiditas dari sisi aset dan liabilitas

3. Optimalisasi pembiyaan bank agar bank mampu memberikan bagi hasil yang kompetitif pada deposari dan pemegang saham. dari beberapa poin tersebut. Ismail merekomendasikan tiga program terintegrasi yang diusulkan harus diperhatikan dalam pengeloaan risiko likuiditas perbankan syariah di Indonesia, yaitu :
a. Institutional deepening
b. Restrukturisasi manajemen likuiditas di sisi aset dan liabilitas
c. Revitalisasi penggunaan instrumen Syariah yang likuiditas.

\section{KESIMPULAN}

Risiko likuiditas adalah risiko akibat ketidak mampuan bank syariah untuk memenuhi kewajiban yang jatuh tempo dari sumber pendanaan harus kas dan atau aset likuid berkualitas tinggi yang dapat digunakan, tanpa mengganggu aktifitas, dan kondisi keuangan bank. Berdasarkan analisis ini suatu bank sebaiknya harus mempelajari dan memahami keutamaan dan risiko likuiditas itu sendiri untuk mengurangi kemungkinan bank untuk mengarah pada kebangkrutan. Apabila suatu bank sudah bisa mengendalikan likuiditasnya, bank akan mendapatkan kepercayaan dari nasabahnya dan bank tersebut akan menjadi lebih maju dan berkembang.

29 Bambang Rianto. "Manajemen Risiko Perbankan Syariah Di Indonesia", 170
Risiko inheren merupakan risiko yang melekat pada kegiatan bisnis bank syariah, baik yang dapat dikuantiflkasi-kan maupun yang tidak, yang berpotensi memengaruhi posisi keuangan bank. Oleh karena itu, penting bagi bank untuk me-ngelola likuiditas yang cukup sehingga mampu menghadapi perubahan-perubahan kondisi keuangan dan ekonomi apapun. Masalah pengelolan likuiditas adalah masalah yang ber-hubungan dengan kemampuan suatu perusahaan untuk memenuhi kewajiban finansialnya yang segera harus dipenuhi. Jumlah alat-alat pembayaran (alat likuid) yang dimiliki oleh suatu perusahaan pada suatu saat merupakan kekuatan membayar dari perusahaan yang bersangkutan. Suatu perusahaan yang mempunyai kekuatan membayar belum tentu dapat memenuhi. Jadi jika suatu bank atau perusahaan sudah bisa mengelola dan memenuhi kewajiban finansalnya, mereka akan siap untuk mengatasi masalah ke-uangan dan ekonomi yang akan datang kedepannya.

Berdasarkan pada prinsip syariah yang mendasarinya terdapat dua jenis akad penghimpunan dana, yaitu wadi'ah atau mudharabah. Produk dengan akad wadi'ah memiliki risiko likuiditas lebih tinggi karena pemilik dana tidak turut menanggung kerugian maupun pendapatan dari penggunaan dana itu oleh bank. Bank harus bertanggung jawab atas keutuhan dana nasabah.

Penerapan manajemen risiko untuk risiko likuiditas bagi bank syariah, baik secara indivudual maupun bagi bank secara konsolidasi dengan perusahaan anak setidaknya mencakup hal-hal sebagai berikut:

1. Pengawasan aktif dewan komisaris, direksi, dan DPS.

2. Kebijakan, prosedur, dan penetapan limit

3. Proses identifikasi,pengukuran,pemantauan, dan pe-ngendalian risiko, serta SIM risiko likuiditas

Bank syariah juga perlu menambahkan penerapan be-berapa hal dalam tiap aspek sistem pengendalian internal, yaitu sebagai berikut.

1. Bank syariah harus menerapkan pengendalian internal dan kaji ulang independen yang memadai terhadap penerapan manajemen risiko untuk risiko likuiditas yang dilaksanakan oleh Satuan Kerja Audit Internal (SKAI) atau oleh Satuan Kerja Manajemen Risiko (SKMR).

2. Pengendalian internal terhadap proses penerapan manajemen risiko untuk risiko likuiditas yang dilakukan oleh SKAI 


\section{EKSISBANK Vol. 3 No. 1 Juni 2019}

Standar perbankan intenasional mengungkapkan penting-nya hal-hal berikut ini dalam mengelola manajemen likuiditas bank:

1. Penentuan kebijakan manajemen likuiditas yang akurat, bisa dipahami dan akomodatif.

2. danya Komite Aset dan Liabilitas (ALCO).

3. Pembentukan sistem informasi untuk pemantauan dan pelaporan serta.

4. Sistem pengendalian internal yang memadai untuk pengelolaan likuiditas bank.

\section{UCAPAN TERIMA KASIH}

Dengan terselesaikannya karya ilmiah ini, penulis mengucapkan terikmakasih sedalam-dalamnya kepada ,Allah swt atas limpahan karuniadan hidayahnya. penulis dapat menggunakan penelitian dan karya tulis. Dosen pengampun atas bimbangan, arahan dan koreksinya selama penyusunan dan diskusi karya tulis. Kedua orang tua yang telah mendoa-kan dan mendukung saya dalam mengerjakan karya tulis ini. Rekan mahasiswa perbankan syariah atas kerjasama-nya dan dukungan selama penulis mengerjakan karya tulis ini.

\section{REFERENSI}

[1] Rianto Rustam Bambang, Manajemen Risiko Perbankan Syariah di Indonesia. Jakarta, Salemba Empat, 2013
[2] Rifki Islmail. The Management Of Liquidity Risk The Caseof Inonesia,.New York, Durham University,2010

[3] Setyowati Endang, Fahmi Kurniawan. Manajemen Likuiditas Perbankan Syariah. http://shariaeconomy. blogspot.com/2008/11 manajemen-likuiditas-perbankan-syariah.html 2008

[4] Ariani risa6, Manajemen Likuiditas Perbankan Syariah http://risaariani6.blogspot.com/2012/06/manaje me-likuiditas-perbankan-syariah.html.

[5] R Antariksa. Pengaruh Risiko Likuiditas Terhadap Profitabilitas. Jakarta, Universitas Indonesia. 2015

[6] Zainal Arifin , Dasar-Dasar Manajemen Bank Syariah. Jakarta, Azkia Publisher 2002

[7] Fathani Achmad, Manajemen Likuiditas Bank Syariah, dari website http://myfhany.blogspot.com/2019/05/ manajemen-likuiditas.myfhany.html? $\mathrm{m}=1$.

[8] My Fingers, Manajemen Likuiditas, dari wibsate http://makalahkuindonesia.blogspot.com/2017/ 04/manajemen-likuiditas.html?m=1.

[9] Febby Varas Savitri, Risiko Likuiditas Pada Bank Syariah Di Indonesia dari website http:// makalahkuindonesia.blogspot.com/2017/04/ manajemenlikuiditas.html?m-1. 